\title{
The Combination of Realistic Rationality and Humanistic Thought
}

\author{
Rurui Sun ${ }^{1}$ \\ ${ }^{1}$ Jilin Agricultural Science and Technology University, Jilin City, Jilin Province, P.R. China
}

Keywords: Daniel Defoe; values; innovation.

\begin{abstract}
Values is the core of social cultural system; it is the important component of individual outlook and philosophy. Its essence is the value standpoint, attitude and basic idea of the subject. Defoe's values were the important components in the meaning of innovation on English Realistic literature in the 18th century. The value system had come into being and developed gradually from the 18th century in order to meet the needs of developing trend in the soil of western culture. It had inherited and developed the literary tradition in the form, which reflected the positive life attitude and man's wisdom and productive power with some new ideas on labor creating different values.
\end{abstract}

\section{Introduction}

Robinson Crusoe is considered as the most popular novel in the west. It's the combination of humanism and the realistic rationality. Robinson is a very realistic character in Defoe's virtual world. Due to the Enlightenment and the industrial revolution, Defoe' ${ }^{\prime}$ s purpose met the tastes of the vast bourgeoisie, and his works must adapt well to the mass and was gradually accepted by the public. The interests and attitudes of the bourgeois value category were successfully expressed in Daniel Defoe's works. Defoe had simply ignored the sentiment and art creation in the early romanticism, and described event developing process so as to meet a real-value heroic world for readers, that is to say, the recognition of the world is in accordance of its original features. Defoe's works paid much attention to the practical problems of our lives. The humanistic value thought, with its paying attention to the reality, is different from the humanistic works with the early romantic style.

Robinson had experienced the severe environmental condition; the deserted island was covered by desert and Gobi, a lonely and sad life. Robinson had to do labor, hunting food, domesticate goat, plant crop, manufacture tool and build cave etc, which would embody the adventurous spirit and willpower of the new bourgeoisie, thus is a historically progress. In this way, the narration of the exploration and pursuit of Robinson, artistically epitomed and embodied the image of bourgeoisie and colonialists when the bourgeoisie were on its rising and it also described the development of bourgeois thoughts. For the sake of self existence, Robinson was engaged in different labor on the desert island. As to the theme, the novel depicted Robinson's diligence, bravery and persistence in an isolated place. The new circumstance enabled Robinson to be a self-reliant man. Work was the first need of his life; he asked for substance from nature and challenged to nature. It shows that human value activity is gradually exerting an important action as effectual means for human to know and change the objective world. Without tool and helper, at first, although Robinson made efforts and spent much time, his collection toward life could not attain the fundamental level. He repaired and improved the wooden board to spend his 42 days. Robinson, worried but not disappointed, he hoped to find out the reason why it lost so as to collect some suggestion for how to succeed in survival, and a new restarting strategy. He made a canoe at the seaside in two more years. Sowing rice-wheat for life, he despised harsh environment and natural calamity but sought an ideal state of life. The fight against harsh environment once again made clear to all: to adhere to labor and creation, brave exploration and logic thoughts is the fundamental guarantee for people to overcome all difficulties and obstacles:

Robinson Crusoe was influenced deeply by the humanism during the Renaissance in Italy. From Robinson's nautical free choice to rational thought in encountering difficulties, and this mundane viewpoint, this is the embodiment of humanistic value ideological core. From Robinson Crusoe, the paper makes an exposition of the influence of humanistic ideas on the literature, and the development and changes of humanistic value. Robinson, loving for navigation but not other external causes, his 
trip around the world was without regard to parents' opposition, so he could completely control his own fate. Robinson drifted himself to a desolate island, after the ship was destroyed during a storm and crew lost. In Robinson's action, "so I went to work, and with the Carpenter's Saw I cut a spare Top-mast into three Lengths, and added them to my Raft, with a great deal of Labor and Pains, but hope of furnishing my self with Necessaries, encouraged me to go beyond what I should have been able to have done upon another Occasion. $\cdots \cdot \cdots$ and I found a strong Current of the Tide set into it, so I guided my Raft as well as I could to keep in the Middle of the Stream: But here I had like to have suffered a second Shipwreck, which, if I had, I think verily would have broke my Heart." Facing to original, strange world, he did not make any prayer and meditation; he could not stop for death. Such a practice of Robinson is just contrary to the literary works of realism value. In Out of Egypt in The Old Testament, it says, Moses led Israeli people to a wilderness to escape from the cruel war, because of Israeli people's voluntary obedience in God; God helped Israeli to tide over the difficulty. Robinson, with protestant belief and individual responsibility principle, accepted the reality to realize his value during the process of struggling with reality, going into prompt action, making the raft to convey cargo and passenger to the ashore from the wrecked ship. By working hard, he got gunpowder, firearm, food and iron tool, etc from the ship. These goods played a key role in the cruel condition. It was necessary to grasp any opportunity to protect his own life, only development can promote conservation. So Robinson can survive and develop. If then Robinson is irrational, dominated by the worship of the God, he will inevitably die out.

By caring for the defects caused by the uncertainty of human life, the humanists raised people's examining to the human status and meditating to their own weakness, so as to lead people to change these unfavorable factors and pursued the perfect harmonious life. This value viewpoint is mainly manifested in Robinson Crusoe. Robinson found some seeds and began to plant them, but he harvested nothing because of the ignorance of the regular pattern of climate. Robinson didn't discourage but struggled constantly. After many failures, finally he achieved his aim. Humanists considered that human being was different from the object; people's ability to analyze and ponder could reached perfection by the improvement of conditions and by making a correct judgment, and human were the full of observation and reasoning ability."The first time I went out I presently discovered that there were Goats in the Island, which was a great Satisfaction to me; but then it was attended with this Misfortune to me, viz. That they were so shy, so subtle, and so swift of Foot, $\cdots$ from whence I concluded, that by the Position of their Opticks, their Sight was so directed downward, that they did not readily see Objects that were above them; so afterward I took this Method, I always claimed the Rocks first to get above them, and then had frequently a fair Mark." On the above elucidation, we can clearly notice the humanistic value influence on the novel. But Defoe is not an absolute pure humanist, and some non-humanist factors can be found in his works.

Humanism developed with the growth of social economy and politics. Humanist values were the foundation stone of the creation, and should be in harmony with other ideological concepts. Defoe had humanistic value as the main stream, and accepted some other concepts. The development and changes of the humanism value in Robinson Crusoe reflected the relationship of humanism and money worship, such as when Robinson conveyed cargo and passenger to the shore from the wrecked ship, in his view, people's validity was considered as a standard. "in another I found about Thirty six Pounds value in Money, some European Coin, some Brazil, some Pieces of Eight, some Gold, some Silver. I smiled to my self at the Sight of this Money, O Drug Said I aloud, what art thou good for, Thou art not worth to me, no not the taking off of the Ground, one of those Knives is worth all this Heap, I have no Manner of use for thee, even remain where thou art, and go to the Bottom as a Creature whose Life is not worth saving." Robinson thought that gold coins couldn't be compared with firearm, gunpowder, rope and food. But Robinson did not abandon the coins, he stored them. From this point, we can see an unreal fantasy (to use gold coins again getting away from the desolate island), for a half-mundane mixture, it is not an absolute pure humanist. Viewing Defoe's humanism tends to egoism from the relationship between man and nature, Robinson found a small animal on the shore and threw some food to it. This is a humanistic tolerance view; he refused the small animal's 
request again. The tolerance view in the small animal accords with humanistic value spirit, but its development tendency is inclined to egoism.

Robinson is a pioneer with humanism value and his own religious view. In Robinson Crusoe, "How when we are in (a Quandary, as we call it) a Doubt or Hesitation, whether to go this Way, or that Way, a secret Hint shall direct us this Way $\cdots$ Upon these, and many like Reflections, I afterwards made it a certain Rule with me, That whenever I found those secret Hints, or pressings of my Mind, to doing, or not doing any Thing that presented; or to going this Way, or that Way, I never failed to obey the secret Dictate." According to this value idea, it can be seen that Robinson is an Englishman, with the belief of God. God only helps industrious and brave man in Robinson's view. God is not a sovereign authority, the relationship between God and man is for a partnership, which can be regarded as the spiritual prop of the bourgeoisie-longing for wealth. It also shows that Robinson possesses the certain characteristics of the rationalist, but this is a non-mainstream, people's feeling and thought were more expressed in Robinson. When Robinson found a footprint on the beach, he fled to his cave with a great panic, is there Devil here? He had a careful study of the footprint; he searched for possible evidence in the surrounding. His reaction is similar to a scientist and police by experiment and clues. Through scientific analysis, human's footprint had been proven strictly. Robinson's fear is realistic and credible, to admit human's shortcomings, the hero is as a human hero, it emphasized the factor of human being himself, and from this we can see the mainstream of humanism value.

Defoe's values become the focus of attention. People in every era can get some enlightenment from them. The subjective initiative of self-transcendence of exploring the unknown world in the depth of Human nature, innovative thinking and unique aesthetic modality are really the deep gene and successful mystery of Defoe's values. Desert-island spirit exhibits the self-surpassed subjective initiative spirit of independence in the new bourgeoisie. Defoe showed us the true value world by the combination of realistic rationality and humanism and revealed the relationship between value ideological system and the subjectivity by the carrier of knowledge. But, Puritanism exerted special influence on Robinson's molding, and Robinson was endowed with the double personality of rising bourgeoisie and Puritan. Because of the special ages, Defoe's values have some colonial thought, irrational factors and religious superstition etc. So we should profoundly analyze Defoe's values from spiritual level. Only by this can we do justice, reason and objective evaluation to Defoe.

Defoe, with humanism value as the center, involved naturalism, idealism, realism and colonialism value, etc. This novel analyzed the influence of labor on human beings. Human being is the subject of society, and labor, the core of human nature, is a process of human life by self-producing and self-development. It is the basic way to promote people's overall development and life value. Defoe summarized that creativity had played an important function in promoting the forming of the new value concept. Robinson's pioneering spirit, progressive significance and promoting effect for the future world, show strong transcendental characteristics.Defoe portrayed Robinson, the hero full of struggling spirit; a great success had been made in the course of striving for life and ideal. Meanwhile, the fearless perseverant scientific spirit is worthy of positive appraisal and learning for ever. The hero is a realistic hero rather than the fantastic one. Daniel Defoe, the famous novelist in the 18th century of Britain, was praised as the realistic pioneer in Britain, first adopting the style of fiction to deal with social customs, his inheritance and development in the humanistic value ideology had produced profound and positive impact on the later novel creation.

\section{References}

[1] Alkon, Paul. Defoe and Fictional Time [M]. Athens: University of Georgia Press, 1979.

[2] Backscheider, Paula R. Daniel Defoe: His Life [M].Baltimore \& London: John Hopkins University Press, 1989.

[3] Bowen, Elizabeth. English Novelists [M]. London: Collins Co.LTD, 1942.

[4] Bastian, F. Defoe's Early Life [G].London \& Basingstoke: Macmillan, 1981. 